\title{
Analysis of the microstructure of Xenodontinae snake scales associated with different habitat occupation strategies
}

\author{
Rocha-Barbosa, $O{ }^{a *}$ and Moraes e Silva, RB. ${ }^{\text {a b }}$ \\ aLaboratório de Zoologia de Vertebrados (Tetrapoda) - LAZOVERTE, Departamento de Zoologia, \\ Instituto de Biologia Roberto Alcantara Gomes - IBRAG, Universidade do Estado do Rio de Janeiro - UERJ, \\ Rua São Francisco Xavier, 524, Maracanã, CEP 20550-013, Rio de Janeiro, RJ, Brazil \\ 'Programa de Pós-Graduação em Biologia Animal, Universidade Federal Rural do Rio de Janeiro - UFRRJ, RJ, Brazil \\ *e-mail: obarbosa@uerj.br
}

Received December 13, 2007 - Accepted February 25, 2008 - Distributed August 31, 2009

(With 1 figure)

\begin{abstract}
The morphology of many organisms seems to be related to the environment they live in. Nonetheless, many snakes are so similar in their morphological patterns that it becomes quite difficult to distinguish any adaptive divergence that may exist. Many authors suggest that the microornamentations on the scales of reptiles have important functional value. Here, we examined variations on the micromorphology of the exposed oberhautchen surface of dorsal, lateral, and ventral scales from the mid-body region of Xenodontinae snakes: Sibynomorphus mikani (terricolous), Imantodes cenchoa (arboreal), Helicops modestus (aquatic) and Atractus pantostictus (fossorial). They were metallized and analyzed through scanning electron microscopy. All species displayed similar microstructures, such as small pits and spinules, which are often directed to the scale caudal region. On the other hand, there were some singular differences in scale shape and in the microstructural pattern of each species. S. mikani and I. cenchoa have larger spinules arranged in a row which overlap the following layers on the scale surface. Species with large serrate borders are expected to have more frictional resistance from the caudal-cranial direction. This can favor life in environments which require more friction, facilitating locomotion. In H. modestus, the spinules are smaller and farther away from the posterior rows, which should help reduce water resistance during swimming. The shallower small pits found in this species can retain impermeable substances, as in aquatic Colubridae snakes. The spinules adhering to the caudal scales of A. pantostictus seem to form a more regular surface, which probably aid their fossorial locomotion, reducing scale-ground friction. Our data appear to support the importance of functional microstructure, contributing to the idea of snake species adaptation to their preferential microhabitats.
\end{abstract}

Keywords: scales, microstructure, snakes, Xenodontinae, SEM.

\section{Análise da microestrutura de escamas de serpentes Xenodontinae em associação à ocupação de diferentes microhabitats}

\begin{abstract}
Resumo
A morfologia de muitos organismos parece estar relacionada ao ambiente em que eles vivem. No entanto, muitas serpentes são tão similares nos seus padrões morfológicos que se torna difícil distinguir qualquer divergência adaptativa existente. Muitos autores sugerem que as micro-ornamentações nas escamas de répteis possuem importante valor funcional. Neste trabalho, examinamos variações na micromorfologia da superfície oberhautchen exposta das escamas ventrais, laterais e dorsais da região medial de serpentes Xenodontinae: Sibynomorphus mikani (terrestre), Imantodes cenchoa (arbórea), Helicops modestus (aquática) e Atractus pantostictus (fossorial). Estas foram metalizadas e analisadas por microscopia eletrônica de varredura. Todas as espécies apresentaram microestruturas similares, tais como microcovas e espículas, que estão normalmente orientadas para a região caudal da escama. Por outro lado, houve algumas diferenças singulares em relação ao formato da escama e padrão microestrutural de cada espécie. S. mikani e I. cenchoa possuem espículas grandes arrumadas em linhas que sobrepõem as camadas seguintes da superfície da escama. Em espécies que possuem longas denticulações sobrepostas sobre as bordas posteriores das células, é esperado que haja uma maior resistência friccional da direção posterior para anterior das escamas. Isso pode favorecer a vida em ambientes que precisam de maior atrito, facilitando a locomoção. Em H. modestus, as espículas são menores e mais afastadas das linhas posteriores, o que pode reduzir o atrito com a água durante a natação. As microcovas mais rasas encontradas nesta espécie podem reter substâncias impermeáveis, como nas serpentes Colubridae aquáticas. As espículas que aderem às escamas caudais de $A$. pantostictus parecem formar uma superfície mais regular, o que
\end{abstract}


provavelmente auxilia na locomoção fossorial, reduzindo o atrito com o solo. Nossos dados parecem corroborar a importância da microestrutura funcional, contribuindo para a hipótese de adaptação das espécies de serpentes aos seus microhabitats preferenciais.

Palavras-chave: escamas, microestrutura, serpentes, Xenodontinae, MEV.

\section{Introduction}

The morphology of organisms is generally well matched to the environment, supposedly because expression of their genes is tailored at population or at individual level to suit local conditions (Aubret et al., 2004). Teixeira-Filho et al. (2001) associated the use of different microhabitats, terrestrial occupation and occupation of smooth bromeliad leaf surfaces with variations in claw curvature of lizard species inhabiting restinga habitats. However, many snakes and other Squamata are so similar in their morphological patterns that it becomes difficult to distinguish adaptive divergences, since they are imperceptible to the naked eye.

Electron microscopy thus becomes a very important tool in uncovering such differences, for it allows the analysis of microstructures present in squamates. Several recent studies have suggested a functional significance for microornamentation (Manderson, 1966; Porter, 1967; Steward and Daniel, 1973; Gans and Baic, 1977; Smith et al., 1982; Renous, et al.,1985; Gower, 2003) or have simply described microanatomy (Arroyo and Cerdas, 1985; Chiasson and Lowe, 1989; Velloso et al., 2005). Microstructures have also been used as tools in taxonomy (Hogue and Santos 1953; Dowling et al., 1972; Stewart and Daniel, 1975) and in ontogenetic and/or evolutionary studies of squamates (Peterson, 1985; Harvery 1993; Harvery and Gutberlet Jr, 1995).

Studies on the relationship between ecology and morphology (i.e., ecomorphology) of animals may account for some natural selection issues based on the partitioning of resources, such as space and food in a given community (Ribas et al., 2004).

This work aimed to verify the existence of microstructure variation on the surface of scales of Xenodontinae snakes occupying different microhabitats (terricolous, arboreal, aquatic and fossorial), to search for the existence of ecomorphological relations between the species studied and their environment.

\section{Material and Methods}

Eighty-three adult specimens of four species of snakes of subfamily Xenodontinae were analyzed: nineteen adult specimens of Sibynomorphus mikani (Schlegel, 1837) (12 females and 7 males; terricolous); twenty adult specimens of Atractus pantostictus (Boulenger, 1885) (9 females and 11 males; fossorial); seventeen adult specimens of Imantodes cenchoa (Linneaus, 1758) (11 females and 6 males; arboreal) and twenty-seven adult specimens of Helicops modestus (Günther,1861) (16 females and 11 males; aquatic). All of them con- sisted of museum specimens from the Alphonse Richard Hoge collection at the Instituto Butantan (IB).

In an attempt to avoid errors derived from phylogenetic factors, the species chosen all belong to the same subfamily (Xenodontinae).

Dorsal, lateral and ventral scales were taken from the mid-region of the body of five adult individuals (males, 2 scales, and females, 3 scales) of each species. The scales were placed in numbered tubes and duly identified for each species. Distilled water and neutral soap were added to the tubes. Each tube was manually shaken for about 1 minute to remove any probable impurities. Scales were then removed, washed and left to dry at room temperature for about 5 minutes.

Aluminum plates of $2 \mathrm{~cm}^{2}$ were fashioned, to which scales were affixed with double-faced adhesive tape. The plates featured numbered quadrats to identify the species and the body part from which scales were removed, for each snake. This method allowed observation of a greater number of scales per session of scanning electron microscopy (from 5 to 6 scales per session).

The material was metallized using a Balzers ${ }^{\circledR}$ FL-9496 metallizer. Scales were later analysed and photographed under a scanning electron microscope (SEM) under various magnifications. Aspects such as border microstructure and format of scale surfaces were observed.

\section{Results}

The borders of all scales analysed were smooth, i.e., without any type of protuberance or depression. However, on the dorsal scales of Atractus pantostictus, a totally smooth area was detected on the border surface, following the contour of the scale body microornamentation (Figure 1a). This pattern was observed only in this species.

Microstructure of scale surfaces revealed structures common to all the species investigated, such as spinules and pits, but the way in which these structures were disposed provided microstructural models that expressed particularities of scale microanatomy for each species studied.

Most scales have a surface covered with rows of elongated plates, which overlap like roof tiles. A great number of spinules project over the next plates of the upper plates' lower border. Spinules are always oriented towards the scale caudal direction. The great number of pits present on the surface of the scales is also frequent.

In $S$. mikani the spinules, large and pointed (Figure 1b), resemble the teeth of a comb. The pits on 
the surface of the scales are similar to those found on the snake Imantodes cenchoa (Figure 1c).

Atractus pantostictus presented scales with a singular microstructural pattern. Spinules are evident, but seem to be fused to the posterior plates, forming a more uniform surface, without exposed denticulations (Figure 1d). The pits were not observed in scales of this species.

In the snake $H$. modestus, plate borders were a good deal more distant from one another than in the other species studied. In addition, observing the surface of the plates it was possible to see that the pits present seem to be shallower than the pits in S. mikani and I. cenchoa. Another important datum is that in $H$. modestus the spinules present at the border of plates are much smaller (characterising a serrated border) than in the other species (Figure 1e).

\section{Discussion}

The locomotory specialisations of snakes reflect differences in their morphology, associated with different modes of predation and the properties of the substrates on which they move (Pough et al., 2003). Spinules and pits may help to increase attrition in reptiles that live on rocks, such as some squamates. Structures such as longitudinal ridges characteristic of limbless squamates or short legs may facilitate locomotion on inclined surfaces (Smith et al., 1982). This entitles us to suppose that environmental pressures have a significant influence not only on the animal's macrostructure, but on its microstructure as well.

Stewart and Daniel (1973) have reported that the smooth scales observed in the fossorious lizard Anniella pulchra may confer greater efficiency to ground locomotion, by reducing attrition. The microstructures on the scales of Atractus pantostictus seem to be arranged so as to aid in reducing attrition during ground locomotion. The spinules fused to the lower layer of the next row form a less irregular and thus smoother surface when compared to the scales of I. cenchoa, S. mikani and $H$. modestus. Reduced friction promotes efficiency in lateral undulation (Gans and Baic, 1977).

Analyzing scale microstructure in snakes of the Uropeltidae family, Gower (2003) proposed that a "smoother" and more regular microornamentation may confer advantages to underground living, possibly by reducing the adhesive force of moist soils on these snakes' scales.

Additionaly or alternatively, in species that have long denticulations overlapping the posterior borders of each spinule row, greater frictional resistance of scales from the posterior to the anterior direction is to be expected (Gower, 2003). These features should have significant importance in terricolous and arboreal snakes, since they require greater attrition for locomotion, in contrast to, e.g., aquatic snakes, in which excessive attrition hampers locomotion.
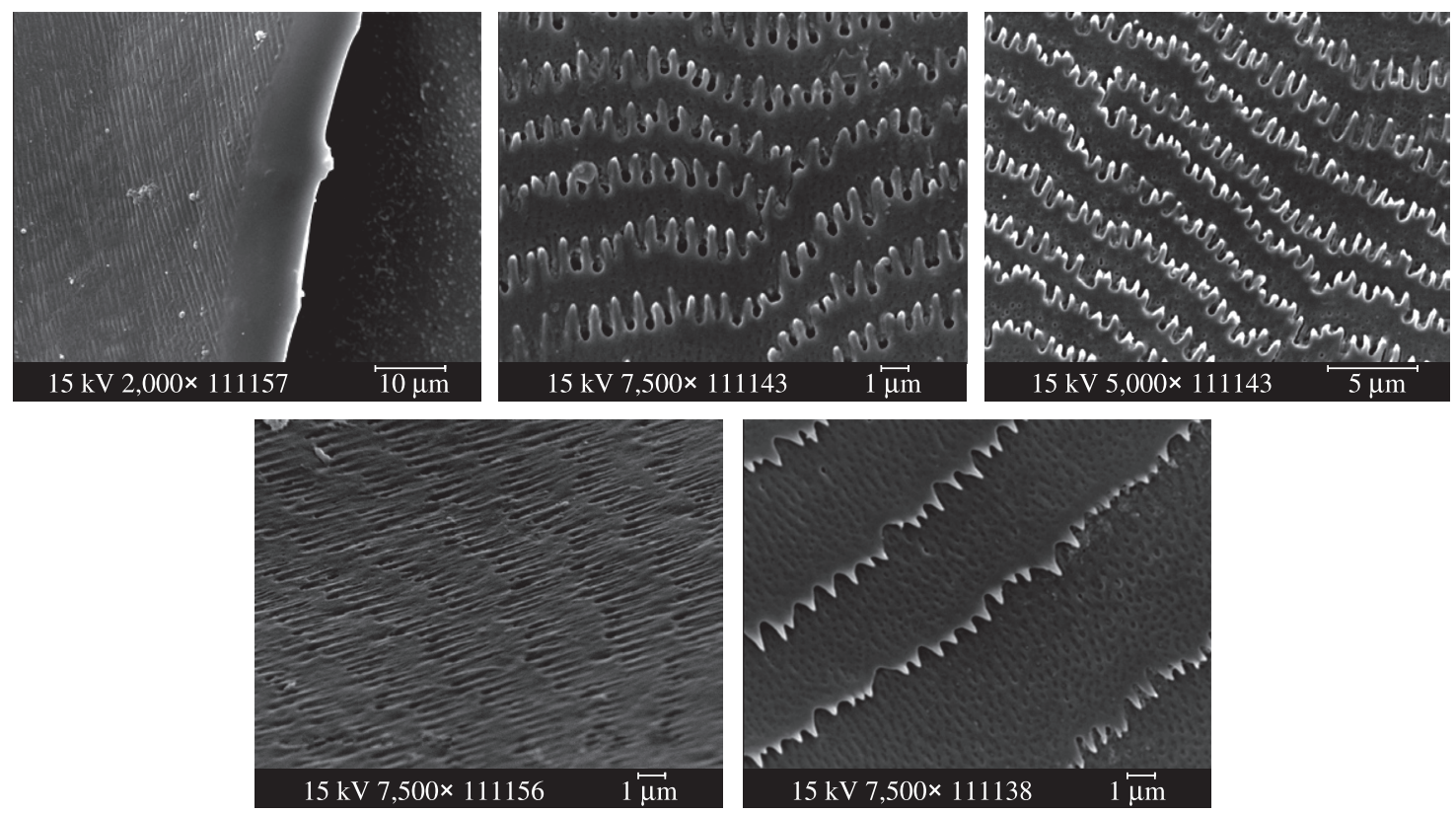

Figure 1. a) Surface of a dorsal scale of Atractus pantostictus, showing a border without apparent microstructures, magnified 2,000×; b) Surface of a lateral scale of Sibynomorphus mikani (terricolous), showing the spinules in rows and micropits over the next rows $(7,500 \times)$; c) Surface of a lateral scale of Imantodes cenchoa (arboreal), showing spinules and micropits $(5,000 \times)$; d) Surface of a ventral scale of Atractus pantostictus (fossorial), showing spinules fused to posterior layers (7,500×); and e) Surface of a dorsal scale of Helicops modestus (aquatic), showing its smaller and serrated spinules, and the shallow micropits $(7,500 \times)$. 
In S. mikani and I. cenchoa a variation in the concentration and size of spinules, as well as in the spaces between them, can be seen. Both belong to the subfamily Xenodontinae and are nocturnal, but differ as to their preferred niche: Sibynomorphus mikani lives on the ground, while $I$. cenchoa inhabits tree tops. Comparing to other species in the same subfamily, our results suggest a strict relationship between spinule variation pattern and these species' preferred habitats (Velloso et al., 2005).

The similarities found between S. mikani and I. cenchoa may be related to their capacity to move in environments requiring a greater degree of attrition. Large spinules in scales, such as those found in I. cenchoa (Figure 1c), could increase anchorage when climbing for instance a tree trunk, and the microornamentation on the scales of S. mikani (Figure 1b) may promote increased efficiency in ground locomotion.

Price (1982) found morphological similarities in the micrornamentation of the scales of aquatic, arboreal, and fossorial snakes, and concluded that microornamentation has a more taxonomic than adaptive function. However, it is likely that small differences in microstructure conformation may bring great benefit to the occupation of distinct microhabitats, and during squamate evolution synapomorphies may have arisen giving the same solution to different adaptive problems. Even when the microstructural form is similar, the distribution and organization pattern differ, which gives a characteristic microstructure to each snake (Arroyo and Cerdas, 1985).

Gower (2003) does not discard the idea that variation in scale microstructure corresponds to different environmental conditions to which the organisms were exposed during the acquisition of these microornamentations. The study of microstructural variation thus must take into account the effects of selective pressures brought about by the peculiarities of each environment.

Microornamentation in the scale surface of the snake H. modestus probably can help in its adaptation to the aquatic environment. Smaller spinules, of serrated aspect, disposed in overlying rows, much farther from one another, possibly help in diminishing the resistance generated by water movement, and the quite shallow pits on the scale surfaces suggest an improvement in the snake's hydrodynamic performance.

Chiasson and Lowe (1989) have suggested that the pits present on the scale surface of Asiatic aquatic Colubridae may contain impermeabilizing substances. These authors based themselves on the discovery of fatty acids present in the surface of these snakes' scales. It is likely that these fatty acids (or similar) may also be found in the scales of $H$. modestus, but only further studies can provide data to test this hypothesis.

Observation of widely diverging microstructural patterns allows us to conclude that, over the course of evolution, modifcations arose not only in visible aspects, but also in microstructures, and that such alterations allowed optimal adaptation of organisms to their environmental niche (Velloso et al., 2005). Stewart and Daniel (1973) underscore that differences in microornamentation allow a functional interpretation. Williams and Peterson (1982) state that the investigation of significant adaptation in cases of morphological divergences may provide ideas of new evolutionary adaptive complexes.

The four species studied presented several striking differences in the microscopic form of scales, suggesting that these differences may actually be the result of environmental selective pressures, and that such changes acted positively, influencing the life mode and determining the ecosystem spaces more favorable to these animals' survival. The contributions from the study of microstructure may provide important data to answer a series of questions related to the adaptation of squamates to the most diverse habitats.

Acknowledgements - FAPERJ (Proc. No E-26/171.310/2001) for financial support. Prof. Gustavo Aveiro Lins (UERJ), Maria da Graça Salomão, Giuseppe Puorto and Valdir José Germano (IB) for technical support. Humberto Moura-Neto for help with the English translation. PROCIÊNCIA/UERJ Program. CRBio 02085/84.

\section{References}

ARROYO, O. and CERDAS, L., 1985. Microestructura de las escamas dorsales de nueve especies de serpientes costarricenses (Viperidae). Revista de Biología Tropical, vol. 34, no. 1, p. 123-126.

AUBRET, F., SHINE, R. and BONNET, X., 2004. Evolutionary biology: adaptive developmental plasticity in snakes. Nature, vol. 431, p. 261-262.

CHIASSON, RB. and LOWE, CH., 1989. Ultrastructural scale patterns in Nerodia and Thamnophis. Journal of Herpetology, vol. 23 , no. 2, p. 109-118.

DOWLING, HP., GILBOA, I., GENNARO, DE. and GENNARO, JF., 1972. Microdermatoglyphics: a new tool reptile taxonomy. Herpetology Review, vol. 4, p. 200

GANS, C. and BAIC, D., 1977. Regional specialization of reptilian scales surfaces: relation of texture and biologic role. Science, vol. 195, p. 1348-1350.

GOWER, DJ., 2003. Scale microornamentation of uropeltid snakes. Journal of Morphology, vol. 258, no. 2, p. 249-268.

HARVERY, MB., 1993. Microstructure, ontogeny, and evolution of scale surface in xenosaurid lizards. Journal of Morphology, vol. 216, p. 161-177.

HARVERY, MB. and GUTBERLET Jr., RL., 1995. Microstructure, evolution and ontogeny of scales in Cordylid and Gerrhosaurid Lizards. Journal of Morphology, vol. 226, p. 121-139.

HOGE, AR. and SANTOS, PS., 1953. Submicroscopic structure of "stratum corneum" of snakes. Science, vol. 118, p. 410-411.

MANDERSON, PF., 1966. Histological changes in the epidermis of the tokay (Gecko geckko) during the sloughing cycle. Journal of Morphology, vol. 119, p. 39-50.

PETERSON, JA., 1985. The microstructure and evolution of scale surfaces in xantusiid lizards. Herpetologica, vol. 41, p. 298-324 
PORTER, WP., 1967. Solar radiation through the living body walls of vertebrates, with emphasis on desert reptiles. Ecological Monographs, vol. 37, no. 4, p. 273-296.

POUGH, FH., JANIS, CM. and HEISER, JB., 2003. A vida dos vertebrados. 3 ed. São Paulo: Atheneu Editora. 307p.

PRICE, RM., 1982. Dorsal snake scale microdermatoglyphics: ecological indicator or taxonomic tool?. Journal of Herpetology, vol. 16, no. 3, p. 294-306.

RIBAS, SC., VELLOSO, ALR., TEIXEIRA-FILHO, P., ROCHA-BARBOSA, O., EVANGELISTA, H. and SANTOS, EA., 2004. Structure of claws and toes of two tropidurid lizard species of Restinga from Southeastern Brazil: adaptations to the vertical use of the habitat. Revista Chilena de Historia Natural, vol. 77 , p. 599-606.

RENOUS, S., GASC, JP. and DIOP, A., 1985. Microstructure of the tegumentary surface of the Squamata (Reptilia) in relation to their spatial position and their locomotion. Fortschritte der Zoologie, vol. 30, p. 487-489.

SMITH, HM., DUVALL, D., GRAVES, BM., JONES, RE. and CHISZAR, D., 1982. The function of squamate epidermatoglyphics. Bulletin of the Philadelphia Herpetological Society, vol. 30, p. 3-8.

STEWART, GR. and DANIEL, RS., 1973. Scanning electron microscopy of scales from different body regions of three lizard species. Journal of Morphology, vol. 139, p. 377-388.

1975. Microornamentation of lizard scales: some variations and taxonomic correlations. Herpetologica, vol. 31, p. $117-130$

TEIXEIRA-FILHO, P., ROCHA-BARBOSA, O., PAES, V., RIBAS, SC. and De ALMEIDA, JR., 2001. Ecomorphological relationship in six lizards species of Restinga da Barra de Maricá, Rio de Janeiro, Brasil. Revista Chilena de Anatomía, vol. 19 , no. 1, p. 45-50.

VELLOSO ALR., LOUGUERCIO MFC. and ROCHABARBOSA O., 2005. Muito além dos nossos olhos. Ciência Hoje, vol. 212, no. 36, p. 61-63.

WILLIAMS, EE. and PETERSON, JA., 1982. Convergent and alternative designs in the digital adhesive pads of scincid lizards. Science, vol. 215, p. 1509-1511. 